\title{
POSTNATAL GROWTH OF THE LUNG
}

\author{
BY \\ M. S. DUNNILL* \\ From the Department of Medicine, Columbia University, and the Cardiopulmonary Laboratory, \\ Bellevue Hospital, New York
}

There are two opposed views on the problem of postnatal lung growth. The first (Short, 1950) considers that the lung at birth has its full complement of alveoli and that further growth takes place by an increase in linear dimensions of existing units. The second, as summarized by Emery and Mithal (1960), proposes that growth occurs by an increase in the number of respiratory units.

Willson (1922) investigated two lungs by serial section and wax reconstruction. He found a dichotomous branching system of the air passages and also that the bronchioles do not decrease in diameter as the periphery is approached. $\mathrm{He}$ thought that the lung of a child, one case " under 13 years of age," was as complex as that of an adult. Broman (1923) suggested that in higher mammals, including man, the number of alveoli at the time of birth had not reached its adult value. In a further investigation into this problem Willson (1928) observed that there was more connective tissue between the air spaces at birth than at later stages of childhood or in the adult. He concluded that postnatal development of the human lung occurred, at least until the age of 7 years, with new branches of the peripheral part of the bronchial tree being formed by "centripetal and centrifugal " processes occurring at the same time. Barnard and Day (1937) found that the lung did not change essentially in structure after the sixth month of foetal life. They inflated foetal lungs artificially by suction in a closed chamber, with or without simultaneous perfusion of the pulmonary artery, and noted that it was impossible to transform the appearance of immature lungs. During and after the sixth month such procedures resulted in the lung resembling that of an adult to varying degrees.

Short (1950), in an exhaustive study of lung growth in rabbits, was the first to employ a truly quantitative approach. He estimated the surface area of the air-tissue interface of lungs at various ages. His main interest was in the continuity or discontinuity of the lining alveolar epithelium. He

\footnotetext{
*Present address: Department of Pathology, The Radcliffe Infirmary, Oxtord.
}

concluded, wrongly as has been shown by the electron microscope studies of Low (1953), that there was no true lining alveolar epithelium. He thought that lung growth was determined by purely physical factors, and showed, to his own satisfaction, that distension of a rabbit lung at birth gave structural results similar to those of growth in vivo.

Loosli and Potter (1959), on the basis of a descriptive study, claimed that, although new pulmonary units may develop up to three years after birth, lung growth after this period can be accounted for by an increase in length and size of respiratory bronchioles, alveolar ducts, sacs, and alveoli. Emery and Mithal (1960) concluded that new alveoli were formed up to the age of puberty.

The purpose of the present paper is to approach the problem quantitatively by determining the number of alveoli present at various ages, and also to estimate the extent of the air-tissue interface and its relationship to body surface area at different stages of growth.

\section{MATERIAL AND METHODS}

Twenty lungs taken from 10 children, aged from birth to 8 years, have been examined, and in addition several adult lungs have been available for comparison. All the children died from conditions other than respiratory disease and all were mature at birth. This accounts for the small number of cases examined. Most children dying in this age range are either premature or suffer from respiratory disorders, and in both these states lung development may not proceed normally, according to Mithal and Emery (1961).

The height and weight of each child was determined and its surface area calculated from the data of Du Bois and Du Bois (1916). The results are shown in Table I.

All the lungs were fixed with formalin vapour employing the method of Weibel and Vidone (1961). As the total lung capacity during life was not known, the lungs were distended to dimensions which were as near as possible the same as those of the internal thoracic measurements of the cadaver but were never less than these. The volume of the inflated lungs 
TABLE I

HEIGHT, WEIGHT, AND BODY SURFACE AREA OF 10 - CHILDREN COMPARED WITH THOSE OF AN ADULT

\begin{tabular}{cccc}
$\begin{array}{c}\text { Age } \\
\text { (mth.) }\end{array}$ & $\begin{array}{c}\text { Height } \\
\text { (cm.) }\end{array}$ & $\begin{array}{c}\text { Weight } \\
\text { (kg.) }\end{array}$ & $\begin{array}{c}\text { Body Surface } \\
\text { Area } \\
\text { (sq. m.) }\end{array}$ \\
\hline Birth & 52 & $3 \cdot 2$ & 0.21 \\
3 & 61 & $5 \cdot 8$ & 0.30 \\
3 & 60 & 5.6 & 0.29 \\
3 & 62 & 5.6 & 0.30 \\
7 & 68 & $8 \cdot 1$ & 0.38 \\
13 & 77 & $10 \cdot 3$ & 0.45 \\
16 & 78 & 10.8 & 0.46 \\
22 & 84 & 11.5 & 0.50 \\
48 & 103 & 16.2 & 0.67 \\
98 & 123 & 25.0 & 0.92 \\
Adult & 175 & 77.0 & 1.90
\end{tabular}

TABLE II

FIXATION CONSTANTS FOR LUNG VOLUME

\begin{tabular}{cc}
$\begin{array}{c}\text { Age } \\
\text { (mth.) }\end{array}$ & $\begin{array}{c}\text { Fixation Constants for } \\
\text { Conversion of Fixed } \\
\text { Volume to Fresh Volume }\end{array}$ \\
\hline Birth & 1.48 \\
3 & 1.25 \\
3 & 1.25 \\
3 & 1.25 \\
7 & 1.27 \\
13 & 1.10 \\
16 & 1.18 \\
22 & 1.07 \\
48 & 1.10 \\
98 & 1.60 \\
Adult & 1.80
\end{tabular}

both before and after fixation was determined by water displacement. The fixation constants for volume were then determined, and these are given in Table II. The processing constants varied less than $5 \%$ from case to case with a mean value of 0.78 for the volume constant for conversion of fixed to processed material.

The methods employed for the determination of the quantitative data required were those described by Dunnill (1962). These may be summarized as follows:

The lungs were cut through the hilum into $1 \mathrm{~cm}$. slices and the volume of parenchyma and nonparenchyma (blood vessels and bronchioles of $1 \mathrm{~mm}$. diameter) determined by the point-counting method. The results are shown in Table III.

Blocks of tissue of standard size, $2.8 \times 2.0 \times 1.0 \mathrm{~cm}$., were selected by the random sampling technique.
Sections were cut at $4 \mu$ and stained by haematoxylin and eosin, periodic acid Schiff, and Masson's trichrome methods.

The volume proportions of alveolar air, alveolar duct air, tissue, and vessels were determined on histological analysis using the Zeiss point-counting. integrating eyepiece. The results are given in Table III.

The enumeration of alveoli was performed using the counting principle of Weibel and Gomez (1962). The number of alveolar transections seen in an area measuring $9.08 \times 10^{-3} \mathrm{sq}$. $\mathrm{cm}$. was counted, and the number per cubic centimetre was then deduced. Ten fields were counted on each slide and seven slides were assessed in each case. The number of alveolar ducts and sacs was enumerated by the same method, but for these the shape constant $\beta$ was taken as being 2.5 , the value for cylinders with a ratio of diameter to length of 0.3. For alveoli a value of 1.55 was used.

The surface area of the air-tissue interface was estimated by the mean linear intercept method (Campbell and Tomkeieff, 1952). A line $0.235 \mathrm{~cm}$. in length was used and 20 random fields on seven slides were assessed. The values for the mean linear intercept are given in Table IV.

Linear dimensions of alveoli were measured using a micrometer eyepiece. The shape of a normal alveolus was taken as a truncated cone surmounted

\begin{tabular}{|c|c|c|c|c|}
\hline \multicolumn{5}{|c|}{$\begin{array}{c}\text { TABLE IV } \\
\text { MEAN LINEAR INTERCEPTS }\end{array}$} \\
\hline $\begin{array}{c}\text { Age } \\
\text { (mth.) }\end{array}$ & $\begin{array}{l}\text { Mean Number } \\
\text { of Alveolar } \\
\text { Transections } \\
\text { per sq. cm. } \\
\left(\times 10^{3}\right)\end{array}$ & $\begin{array}{l}\text { Standard } \\
\text { Error of } \\
\text { Mean } \\
(1) \%\end{array}$ & $\begin{array}{c}\text { Mean } \\
\text { Linear } \\
\text { Intercept } \\
\left(\times 10^{-2}\right) \\
\mathrm{cm} .\end{array}$ & $\begin{array}{c}\text { Standard } \\
\text { Error } \\
(\%)\end{array}$ \\
\hline $\begin{array}{c}\text { Birth } \\
3 \\
3 \\
3 \\
7 \\
13 \\
16 \\
22 \\
48 \\
98 \\
\text { Adult }\end{array}$ & $\begin{array}{l}3 \cdot 72 \\
7 \cdot 76 \\
5 \cdot 56 \\
6 \cdot 39 \\
7 \cdot 04 \\
5 \cdot 11 \\
4 \cdot 91 \\
5 \cdot 75 \\
6 \cdot 39 \\
4 \cdot 72 \\
2 \cdot 94\end{array}$ & $\begin{array}{l}2.0 \\
1.3 \\
1.7 \\
1.9 \\
1.3 \\
2.0 \\
1.6 \\
2.0 \\
1.8 \\
2.0 \\
1.8\end{array}$ & $\begin{array}{l}2.322 \\
1.250 \\
1.630 \\
1.545 \\
1.286 \\
1.571 \\
1.736 \\
1.407 \\
1.469 \\
1.950 \\
2.085\end{array}$ & $\begin{array}{l}2.0 \\
1.5 \\
2.4 \\
2.3 \\
1.8 \\
2.4 \\
1 \cdot 3 \\
1.2 \\
1.7 \\
1.4 \\
1.3\end{array}$ \\
\hline
\end{tabular}

TABLE III

VOLUME OF NON-PARENCHYMA AND VOLUME AND VOLUME PROPORTIONS OF PARENCHYMA DETERMINED BY THE POINT-COUNTING METHOD

\begin{tabular}{|c|c|c|c|c|c|c|c|}
\hline \multirow{2}{*}{$\underset{\text { (mth.) }}{\text { Age }}$} & \multirow{2}{*}{$\begin{array}{l}\text { Lung } \\
\text { Volume } \\
\text { Fresh } \\
\text { (ml.) }\end{array}$} & \multirow{2}{*}{$\begin{array}{c}\text { Volume of } \\
\text { Non- } \\
\text { parenchyma } \\
(\%)\end{array}$} & \multirow{2}{*}{$\begin{array}{c}\text { Volume of } \\
\text { Parenchyma } \\
(\%)\end{array}$} & \multicolumn{4}{|c|}{ Volume Proportions of Parenchyma with Standard Errors* } \\
\hline & & & & $\underset{(\%)}{\text { Alveolar Air }}$ & $\begin{array}{l}\text { Alveolar Duct } \\
\text { Air }(\%) \ddagger\end{array}$ & $\begin{array}{c}\text { Tissue } \\
(\%)\end{array}$ & $\begin{array}{l}\text { Vessels } \\
(\%)\end{array}$ \\
\hline $\begin{array}{r}\text { Birth } \\
3 \\
3 \\
3 \\
7 \\
13 \\
16 \\
22 \\
48 \\
98 \\
\text { Adult } \dagger\end{array}$ & $\begin{array}{r}200 \\
250 \\
355 \\
300 \\
380 \\
550 \\
650 \\
650 \\
990 \\
2,200 \\
5,500\end{array}$ & $\begin{array}{r}10 \\
11 \\
8 \\
8 \\
12 \\
7 \\
9 \\
10 \\
10 \\
10 \\
10\end{array}$ & $\begin{array}{l}90 \\
89 \\
92 \\
92 \\
88 \\
93 \\
91 \\
90 \\
90 \\
90 \\
90\end{array}$ & $\begin{array}{l}44.7( \pm 2.4) \\
50.9( \pm 1.9) \\
50.8( \pm 1.9) \\
59.8( \pm 1.5) \\
49.3( \pm 2.1) \\
59.3( \pm 1.5) \\
61.7( \pm 1.5) \\
56.0( \pm 1.6) \\
65.3( \pm 1.5) \\
59.9( \pm 1.5) \\
59.5( \pm 1.5)\end{array}$ & $\begin{array}{l}30.7( \pm 3.0) \\
34.4( \pm 2.5) \\
30.3( \pm 2.8) \\
25.9( \pm 3.2) \\
37.6( \pm 2.4) \\
26.2( \pm 3.1) \\
25.3( \pm 3.3) \\
34.3( \pm 2.7) \\
21.4( \pm 3.7) \\
30.6( \pm 3.0) \\
29.0( \pm 3.0)\end{array}$ & $\begin{array}{r}23.5( \pm 3.3) \\
13.3( \pm 5.3) \\
17.2( \pm 3.9) \\
12.9( \pm 5.6) \\
11.8( \pm 5.0) \\
12.4( \pm 4.8) \\
11.3( \pm 5.2) \\
9.0( \pm 5.8) \\
11.9( \pm 5.0) \\
7.4( \pm 6.7) \\
10.8( \pm 5.2)\end{array}$ & $\begin{array}{l}1.1( \pm 18.5) \\
1.4( \pm 15.6) \\
1.7( \pm 13.6) \\
1.4( \pm 15.6) \\
1.3( \pm 16.3) \\
2.1( \pm 12.6) \\
1.7( \pm 13.6) \\
0.7( \pm 22.2) \\
1.4( \pm 15.6) \\
2.1( \pm 12.6) \\
0.7( \pm 22.2)\end{array}$ \\
\hline
\end{tabular}

* The errors are the standard errors expressed as a percentage of the individual volume proportions.

+ This is a typical adult male aged 25 years. in the text. 
by a cone (Fig. 3). Sixty typical alveoli were selected for measurement in each case. The measurement of alveolar diameter is subject to considerable methodical error as only a very occasional alveolus is bisected in an histological section. Thus the diameter is persistently underestimated. However, as the main interest in this investigation was the relative change in dimensions with age, this is not too important. An attempt was made to correct for the underestimation of alveolar diameter by multiplying the final mean diameter by an arbitrary factor of 1.25 .

\section{RESUlTS}

Numbers of Alveoli.-The results of the determination of the numbers of alveoli are shown in Table V. It can be seen that there is an increase of over tenfold from birth to adult life. Weibel

TABLE $\mathrm{V}$

RESPIRATORY AIRWAYS

\begin{tabular}{cccc}
$\begin{array}{c}\text { Age } \\
\text { (mth.) }\end{array}$ & $\begin{array}{c}\text { Number of } \\
\text { Alveoli 10 }\end{array}$ & $\begin{array}{c}\text { Number of } \\
\text { Respiratory } \\
\text { Airways } \\
10^{6}\end{array}$ & $\begin{array}{c}\text { Generations } \\
\text { of } \\
\text { Respiratory } \\
\text { Airways }\end{array}$ \\
\hline Birth & 24 & $1 \cdot 5$ & \\
3 & 86 & $1 \cdot 8$ & 21 \\
3 & 77 & $2 \cdot 5$ & \\
3 & 73 & $2 \cdot 0$ & \\
7 & 112 & $3 \cdot 7$ & 22 \\
13 & 129 & $4 \cdot 5$ & \\
16 & 127 & $4 \cdot 7$ & \\
22 & 160 & $7 \cdot 1$ & \\
48 & 257 & $7 \cdot 9$ & 23 \\
98 & 280 & $14 \cdot 0$ & 23 \\
Adult & 296 & $14 \cdot 0$ &
\end{tabular}

and Gomez (1962) found a mean value of 296 million for the number of alveoli in the adult lung. In Fig. 1 the alveolar number is plotted against age, and it can be seen that there is an exponential increase. A curve with a fairly good fit to the experimental points is given by the equation $N_{t}=$ $N_{A}-\left(N_{A}-N_{B}\right) e^{-s t}$, where $N_{t}=$ number of alveoli at any time $t$ months; $N_{A}=$ number of alveoli in

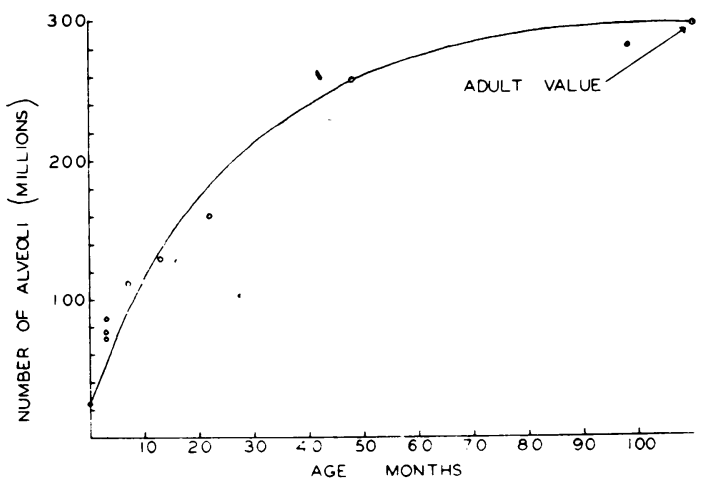

FIG. 1. A graph showing the number of alveoli at various ages. the adult lung; $\mathbf{N}_{\mathbf{B}}=$ number of alveoli at birth ; and $s=a$ constant with the value of 0.04 .

Respiratory AIRWAYS.- It is not possible to distinguish between the second and third order of respiratory bronchioles and the alveolar ducts on a random histological section. For this reason the final three generations of passages have been termed respiratory airways. Their total number can, however, be estimated by the same method as is used for alveoli. The results are given in Table V, and it can be seen that they increase in number from 2 million at birth to 14 million in the adult.

Volume Proportions (Table III).-The most interesting feature here is the high proportion of tissue present at birth compared with that present in the adult lung. This can be seen in sections of lungs fixed by the inflation method immediately after birth, where the quantity of tissue present at the points of division of respiratory bronchioles and alveolar ducts is much greater than in the adult. This tissue consists of loose vascular mesenchyme. The quantity of tissue in the alveolar septal wall is not increased.

AIR-TISSUE INTERFACE.-The area of the airtissue interface at various ages is shown in Table VI. It shows an exponential increase with a maximum in adult life. The area of the air-

TABLE VI

AREA OF AIR-TISSUE INTERFACE

\begin{tabular}{ccc}
$\begin{array}{c}\text { Age } \\
\text { (mth.) }\end{array}$ & $\begin{array}{c}\text { Air-tissue } \\
\text { Interface } \\
\left(\mathrm{m} .{ }^{2}\right)\end{array}$ & $\begin{array}{c}\text { Body Surface } \\
\text { Area } \\
\left(\mathrm{m} .{ }^{2}\right)\end{array}$ \\
\hline Birth & $2 \cdot 8$ & $0 \cdot 21$ \\
3 & $6 \cdot 0$ & $0 \cdot 30$ \\
3 & $7 \cdot 2$ & $0 \cdot 29$ \\
3 & $6 \cdot 2$ & $0 \cdot 30$ \\
7 & $8 \cdot 4$ & $0 \cdot 38$ \\
13 & $12 \cdot 2$ & $0 \cdot 45$ \\
16 & $12 \cdot 8$ & $0 \cdot 46$ \\
22 & $14 \cdot 2$ & $0 \cdot 50$ \\
48 & $22 \cdot 2$ & 0.67 \\
98 & 32.0 & 0.92 \\
Adult & 75.0 & 1.90
\end{tabular}

tissue interface is, however, related in a linear manner to the body surface area, and thus presumably to the oxygen consumption, at the corresponding ages. The relationship is shown in Fig. 2 and corresponds to the equation $\mathrm{S}_{\mathrm{AT}}=$ $42.9 B_{s}-6.82$, where $S_{A T}=$ the area of the air-tissue interface and $\mathbf{B}_{\mathrm{s}}=$ the body surface area.

Linear Dimensions.- It can be seen from Fig. 3 that the dimensions remain relatively constant until the age of 8 years, and that after this age there is an increase. 


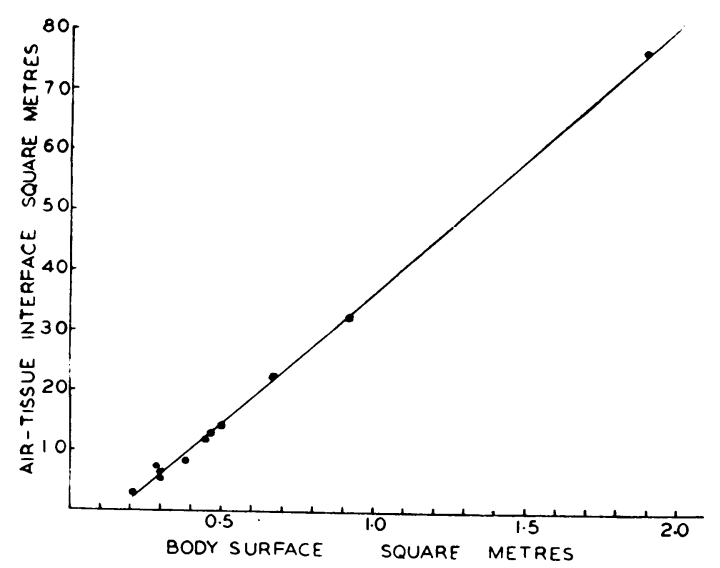

FIG. 2. A graph illustrating the linear relationship between the area of the air-tissue interface and the body surface area during the period of growth.

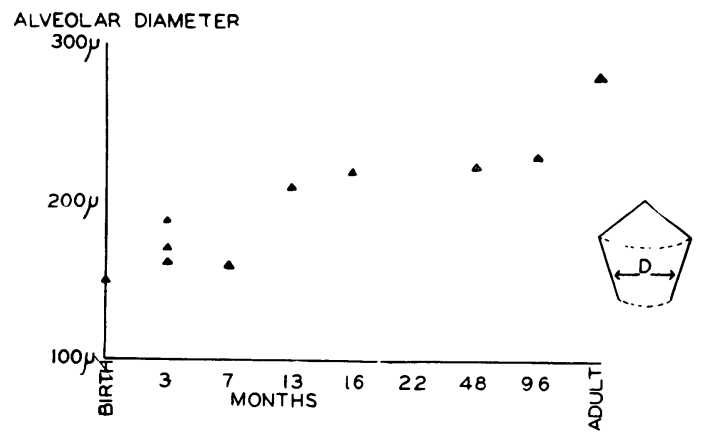

FIG. 3. A chart showing the alveolar diameter at various ages. The position of the diameter in a bisected alveolus is shown. The points on the chart illustrate the mean of 60 measurements in each case.

\section{Discussion}

Short (1950) considered that lung growth was determined by purely physical factors. He found that simple distension of the newborn rabbit lung resulted in a structure resembling the lung of the adult. This implied that the excess tissue seen in the newborn lung represented alveoli in the collapsed state and that growth of the lung consisted merely of the opening out of these structures. This experiment was repeated during the present investigation in one newborn infant, a case not tabulated here. It resulted in rupture of one lung, and subsequent histological examination of the other lung did not reveal a picture resembling that seen in the adult.
The results shown here indicate clearly that the number of alveoli increase in an exponential manner up to the age of 8 years. The volume proportion of tissue declines over this period, and it is reasonable to suppose that the new units are formed from differentiation of the excess tissue present in the neonatal period. This excess tissue, as has been already pointed out, is present at the bifurcation of alveolar ducts and respiratory bronchioles. There is no thickening of the individual alveolar septa which, if present, would of course give rise to diffusion difficulties in the newborn. After eight years of life further growth in lung volume occurs by an increase in linear dimensions. The lung volume doubles between the ages of 8 and 25 years, and this means that the linear dimensions must increase by the cube root of two. Thus an alveolar diameter of $230 \mu$ at 8 years would be expected to increase by 1.2 to $280 \mu$ in the adult. It has been mentioned already that the measurement of alveolar linear dimensions is subject to considerable methodical error. The results shown in Fig. 3 do, however, illustrate the increase in alveolar diameter that occurs between 8 years and adult life.

The number of respiratory passages distal to the first order of respiratory bronchioles increases from approximately 2 million at 3 months to 14 million in the 8-year-old and the adult. Bucher and Reid (1961) have shown that the nonrespiratory air passages down to the level of the terminal bronchioles are complete at birth. Any further increase occurs as a result of formation of distal airways which are respiratory in nature. If a dichotomous system of branching is assumed, the number of examples in any generation, $n$, will be $2^{n}$. In the 8 -year-old and the adult there are 14 million respiratory passages, but unfortunately it is not possible to distinguish those of different generations. If it is assumed that the three distal generations of respiratory passages have been counted, then the generations can be calculated from $2^{n}+2^{n+1}+2^{n+2}=14.10^{6}$, whence $n=21$. Thus in the adult and the 8-year-old there are 23 generations present, assuming the right and left main bronchi to be the first generation. By a similar reasoning, it can be shown that the number at age 13 to 16 months corresponds to two distal generations of respiratory airways with a total of 22 generations. In the 3-month-old there are two million respiratory airways compatible with a single distal generation and a total of 21 generations of airways in all. These values represent averages for each age group, and it is not suggested that in the adult there are 23 generations 
at all points of the periphery of the lung. In some regions there are many more generations and in others fewer (Hayward and Reid, 1952).

It is interesting to note that Cohn $(1939,1940)$ in an experimental study of lung growth and regeneration found in rats that, if lung tissue was excised while the animal was young, regeneration occurred with restoration of lung weight to normal values. This did not mean that after lobectomy a new lobe was formed but that after an interval the total lung weight returned to normal as a result of formation of new units in the remaining lobes. It might be possible for similar regeneration of lung to occur in children up to 8 years during the period of active lung growth, but it seems unlikely that any regeneration would take place after this period.

The information given here on the values of numbers of alveoli and the area of the air-tissue interface may well prove of value in the quantitative assessment of such clinical conditions as pulmonary hypoplasia and the respiratory syndrome of the newborn. They may also be of use in evaluating pulmonary development in the premature infant.

\section{SUMMARY}

A quantitative study of postnatal lung growth has been made and shows that the number of alveoli increases over tenfold between birth and adult life. This increase occurs mainly in the first eight years. After this age, increase in lung volume takes place by increase in linear dimensions of existing alveoli. The mean number of generations of airways increases from 21 to 23, from 3 months to 8 years of age. This increase takes place in the most distal respiratory airways. There is a linear relationship between the surface area of the air-tissue interface and the body surface area during the period of growth. It is suggested that information of this type may well be useful in assessing such conditions as pulmonary hypoplasia, respiratory syndrome of the newborn, and the lung in prematurity.

I am grateful to Miss Nancy Purdum for technical assistance and to Drs. André Cournand, D. M. Gomez, and Dickinson W. Richards for much encouragement and advice. The medical examiners of New York City and Dr. M. Kuschner kindly provided the specimens. The work was supported by grants from the Health Research Council of the City of New York, the United States Public Health Service (USPHS-H-5741 (R1)), and the New York Heart Association.

\section{REFERENCES}

Barnard, W. G., and Day, T. D. (1937). J. Path. Bact., 45, 67. Broman, I. (1923). Anat. Anzeiger, 57, 95.

Bucher, U., and Reid, L. McA. (1961). Thorax, 16, 207.

Campbell, H., and Tomkeieff, S. I. (1952). Nature (Lond.), 170, 117. Cohn, R. (1939). Anat. Rec., 75, 195.

- (1940). J. thorac. Surg., 9, 274.

Du Bois, D., and Du Bois, E. F. (1916). Proc. Soc. exp. Biol. (N.Y.), 13,77 .

Dunnill, M. S. (1962). Thorax, 17, 320.

Emery, J. L., and Mithal, A. (1960). Arch. Dis. Childh., 35, 544.

Hayward, J., and Reid, L. McA. (1952). Thorax, 7, 89.

Loosli, C. G., and Potter, E. L. (1959). Amer. Rev. resp. Dis., 80, No. i, pt. 2 (suppl., p. 5).

Low, F. N. (1953). Anat. Rec., 117, 241.

Mithal, A., and Emery, J. L. (1961). Arch. Dis. Childh., 36, 449.

Short, R. H. D. (1950). Phil. Trans. B., 235, 35.

Weibel, E. R., and Gomez, D. M. (1962). J. appl. Physiol., 17, 343. and Vidone, R. A. (1961). Amer. Rev. resp. Dis., 84, 856.

Willson, H. G. (1922). Amer. J. Anat., 30, 267. (1928). Ibid., 41, 97. 